\title{
適応の指標としての自己概念の研究 *
}

\author{
山形 大 学
}

椎 野 信 治**

\section{問 題}

Snygg と Combs (1949), Rogers によつて自我への 現像学的接近が提唱されて以来, 行動理解あるいは行動 予測に抢ける自己概念の重要性が強調されるようになつ た。とくに, Rogers (1954) は臨床的場面に㧅いて, 治 療過程が進行し適応がよくなるにつれて自己概念も変容 することを示し，実証的研究への端緒をひらいた。そこ で用いられた適応の指標は理想自己と現実自己の分離 (discrepancy) であり，そのずれが大きいものは不適応 の, 小さいものは応適の指標となるとした。その後, Bills（1951）はじめ多くの研究者によつてその有効性が 認められているが, 一方, そのように単純な形でしかも 一義的に適応との関係を扱うことに対する批判がある。 その問題点を列挙すると,(1)適応との関係は一義的ある いは直線的でなく曲線的である。すなわち，一致の度合 いのあまり高すぎる者る，低すぎる者も問題がある。

(2)第 1 の点とも関係するが，高い一致を示す者のなかに 防衛的反応をするるのがあり，一致の高いものがみな適 応がよいとはいえない。(3)現象学的立場をとる人のなか にも，理想自己と現実自己の不一致のみでなく，有意味 な他者 (signifigant others) からどら見られているかと いらことと現実自己の差も適応と密接な関係をもつてい るはずである。(4)現像学的自己のみを扱つて，その客観 性を問題にしていない，などである。しかし，これらの 批判は理想自己と現実自己の不一致が適応の指標として かなり有効なもので，必要であるが必要十分ではないと いら立場からのものである。これらの問題点を考慮した 研究も見られるが，それらの結果は必ずしも一致してい ない。

* Studies on the self concept as the indices of the adjustment.

** by Nobuji Shiino (Yamagata University)
本研究では, これらの批判のうち(3)の問題すなわち, 理想自己と現実自己の差異のみでなく，現実自己と個人 にとつて重要で有意味な他者（友人，母，父）が自分を ぞう認知しているかという他者自己との差異をも扱い， 適応との関係を検討する。なお，自己概念測定の用具と して, 最近, 長島ら (1966) が系統的操作を経て開発, 発展した自己記述 (Self-differential) 尺度を用いること にした。

\section{諸種の自己概念間の差異得点と $Y G$ 性格検查得点との関係}

\section{1. 目 的}

現実自己 $(\mathrm{Sp})$ と理想自己 $\left(\mathrm{S}_{\mathrm{I}}\right)$ 打よび友人・母親・ 父親から見られていると推測する自己 $\left(\mathrm{S}_{\mathrm{F}}, \mathrm{S}_{\mathrm{M}}, \mathrm{S}_{\mathrm{F}} \mathrm{a}\right)$ と 4 つの差異点と Y G 性格検査の下位検査得点との関係 を，次の観点から検討する。すなわち，第 1 亿個々の差 異点がY G性格検查で測られた適応のいかなる領域と密 接な関連をるつかといらことである。その場合の仮説は 現実自己と理想自己の差のように自己内の分離と他者の 交脈を導入した場合の他の 3 つの差異点とでは適応の異 なつた領域を反映するであろらといらことにある。第 2 にどの差異点が適応の指標として有効であるかというこ とである。

\section{2. 方法}

被験者：山形大学で心理学を受講している学生 55 名 (男 11 名, 女 44 名)

測定用具：自己記述尺度 (大学生用 これは自己を記 述する形容詞対 38 項目で構成され 7 段階評定をさせるよ らになつている[付表 1])。ならびにY G 性格検査。

手続き：自己概念の測定では，まず 1 枚の S D尺度を 被験者に配布し, 現実自己 (Sp) についての評定をさせ た。その際の教示は「見たままの自分あるいは現在の自 分について尺度上のあてはまるところに○印をつけてく 
ださい」といらことであつた。評定が終つたら回収し て，次に理想自己 $\left(\mathrm{S}_{\mathrm{I}}\right)$ について評定させた。理想自己 については「こうありたいと思う自分あるいは理想の自 分」について評定するように求めた。以下友人から見ら

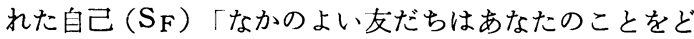
のよらに思つていると推測するか」にもとづく評定，母 親からみられた自己 $\left(\mathrm{S}_{\mathrm{M}}\right)$ 「親はあなたのことをどう 思つていると推測するか」にもとづく評定一一母親がい ない人は世話になつた祖母，伯叔母，姉でもよい一， 父親からみられた自己 $\left(\mathrm{S}_{\mathrm{F}} \mathrm{a}\right)$ 「父親はあなたのことをど ら思つていると推測するか」にもとづく評定一一父親の いない人は祖父，伯叔父，兄でもよい一の順に同様の 手続きで行なつた。実施期日は1965年 5 月10日。

Y G 性格検査は 5 つの自己概念測定を行なつて，1 週 間後に実施した。

結果の処理 : 4 つの差異点は $\mathrm{D}_{\mathrm{PI}}, \mathrm{D}_{\mathrm{PF}}, \mathrm{D}_{\mathrm{PM}}, \mathrm{D}_{\mathrm{PF}}$ と略記する。差異点の算出法は, $\mathrm{D}=\sqrt{\sum_{\mathrm{i}=1}^{\sum^{n}} \mathrm{di}^{2} / \mathrm{n}}$ (各尺 度について 2 つの概念間の差 (di), $\mathrm{n}$ は尺度数) で定義 する。したがつて，差異点の大きいものは自己概念間の 不一致が大きく，より不適応であることが予想される。
各差異について，性差があるかどうかを検討したとこ ろ, Table 1 のように 4 つとも, 有意差が見られなかつ た。

Table 1 差異点の性差の比較

\begin{tabular}{c|c|c|c|c|c|c|c}
\hline & $\mathrm{M}$ & 男 & $\mathrm{F}$ & 女 & \multirow{2}{*}{ 差 } & $\mathrm{t}$ & $\mathrm{p}$ \\
\hline $\mathrm{M}$ & $\mathrm{SI}$ & 1.76 & 0.57 & 1.99 & 0.65 & -0.231 .1029 & $\mathrm{n} . \mathrm{s}$ \\
\hline $\mathrm{DPF}$ & 1.01 & 0.22 & 1.24 & 0.50 & -0.231 .4919 & $\mathrm{n} . \mathrm{s}$ \\
\hline $\mathrm{DPFa}$ & 1.01 & 0.26 & 1.27 & 0.46 & -0.261 .6530 & $\mathrm{n.s}$ \\
\hline $\mathrm{DPM}$ & 1.06 & 0.28 & 1.33 & 0.43 & -0.271 .9706 & $\mathrm{n.s}$
\end{tabular}

そこで，男女をいつしょにしておのおのの差異点ごと にその大きい者10名，小さい者10名を選び，Y $\mathrm{Y}$ 得点の 差を $\mathrm{t}$ 検定によつて比較した。この場合, $\mathrm{YG}$ 得点は粗 点を 5 点法に変換したものを用いた。次に 55 名につい て, 各差異点と Y G 性格検査での因子得点との相関 （Pearsonの積率相関係数）を求めた。

\section{3. 結 果}

4 つの差異点の分布はTable 2 に示すようである。

Tabel 2 差異点の分布

\begin{tabular}{|c|c|c|c|c|c|c|c|c|c|}
\hline \multirow{2}{*}{\multicolumn{2}{|c|}{ 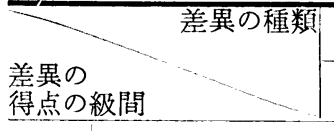 }} & \multicolumn{2}{|c|}{$\mathrm{DP}_{\mathrm{P}}$} & \multicolumn{2}{|c|}{$\mathrm{DPF}_{\mathrm{F}}$} & \multicolumn{2}{|c|}{$D_{P M}$} & \multicolumn{2}{|c|}{ DPFa } \\
\hline & & 実 数 & \multirow{2}{*}{$\begin{array}{l}\% \\
0\end{array}$} & 実 & \multirow{2}{*}{$\frac{\%}{10.9}$} & 矢 数 & \multirow{2}{*}{$\frac{\%}{7.3}$} & \multirow{2}{*}{ 実 数 } & \multirow{2}{*}{$\frac{\%}{12.0}$} \\
\hline 1 & $0.25 \sim 0.75$ & 0 & & 6 & & 4 & & & \\
\hline 2 & $0.75 \sim 1.25$ & 6 & 10.9 & 27 & 49.1 & 25 & 45.5 & 23 & 46.0 \\
\hline 3 & $1.25 \sim 1.75$ & 16 & 29.1 & 17 & 30.9 & 19 & 34.5 & 16 & 32.0 \\
\hline 4 & $1.75 \sim 2.25$ & 19 & 34.5 & 4 & 7.3 & 5 & 9.1 & 2 & 4.0 \\
\hline 5 & $2.25 \sim 2.75$ & 8 & 14.5 & 0 & 0 & 2 & 3.6 & 3 & 6.0 \\
\hline 6 & $2.75 \sim 3.25$ & 3 & 5.5 & 0 & 0 & 0 & 0 & 0 & 0 \\
\hline 7 & $3.25 \sim 3.75$ & 3 & 5.5 & 1 & 1.8 & 0 & 0 & 0 & 0 \\
\hline \multicolumn{2}{|r|}{ 棓 } & 55 & 100.0 & 55 & 100.0 & 55 & 100.0 & 50 & 100.0 \\
\hline & 布 範 囲 & \multicolumn{2}{|c|}{$0.90 \sim 3.66$} & \multicolumn{2}{|c|}{$0.54 \sim 3.37$} & \multicolumn{2}{|c|}{$0.51 \sim 2.54$} & \multicolumn{2}{|c|}{$0.51 \sim 2.68$} \\
\hline & \multicolumn{2}{|c|}{2.45} & \multicolumn{2}{|c|}{1.89} & \multicolumn{2}{|c|}{1.16} & \multicolumn{2}{|c|}{1.22} \\
\hline \multicolumn{2}{|r|}{ S D } & \multicolumn{2}{|c|}{0.68} & & & 0. & & & \\
\hline
\end{tabular}

D $\mathrm{P}_{\text {I }}$ 平均が 2.45 で標準偏差は 0.68， $\mathrm{D}_{\mathrm{PF}}, \mathrm{D}_{\mathrm{PM}}$ ， $\mathrm{D}_{\mathrm{PF}} \mathrm{a}$ などの他者自己との差異は平均が $1.16 〜 1.89$ で標 準偏差は0.44〜0.50である。DPIは他の 3 つより差異が 大きく,ちらばりも大きいことがわかる。また, 差異点と Y G得点の関係を検討する前に 4 つの差異点について,
その大なる者10名と小さい者10名とを比較してみると， いずれもその差は $1 \%$ 水準で有意であつた (Table 3)。

次に, 4 つの差異点の差大群と差小群の Y G下位検査 得点の差を $\mathrm{t}$ 検定した結果は, Table 4 に示すとおりで ある。 
Table 3 差異点の差大群・差小群の差の検定

\begin{tabular}{|c|c|c|c|c|c|c|}
\hline \multicolumn{4}{|c|}{$\begin{array}{l}\text { 差異の種類 } \\
\text { 差大群差小群 } \\
\mathrm{N}=10 \mathrm{~N}=10\end{array}$} & 差 & $t$ & $\mathrm{p}$ \\
\hline \multirow{2}{*}{$\bar{D}_{P I}$} & M & 0.30 & 1. 14 & \multirow{2}{*}{11.5} & \multirow{2}{*}{12.92} & \multirow{2}{*}{$<.001$} \\
\hline & S D & 0.40 & 0.17 & & & \\
\hline \multirow{2}{*}{$D_{P F}$} & $\mathrm{M}$ & 1.93 & 0.70 & \multirow{2}{*}{7.6} & \multirow{2}{*}{7.26} & \multirow{2}{*}{$<.001$} \\
\hline & S D & 0.50 & 0.11 & & & \\
\hline \multirow{2}{*}{$D_{P M}$} & $\mathrm{M}$ & 2.01 & 0.78 & \multirow{2}{*}{7.6} & \multirow{2}{*}{11.81} & \multirow{2}{*}{$<.001$} \\
\hline & S D & 0.28 & 0.14 & & & \\
\hline \multirow{2}{*}{$D_{P F} a$} & $\mathrm{M}$ & 1.88 & 0.73 & \multirow{2}{*}{7.13} & \multirow{2}{*}{7.28} & \multirow{2}{*}{$<.001$} \\
\hline & S D & 0.46 & 0.14 & & & \\
\hline
\end{tabular}

Table 4 DPI の差大・差小群の Y G 得点に扣ける比較

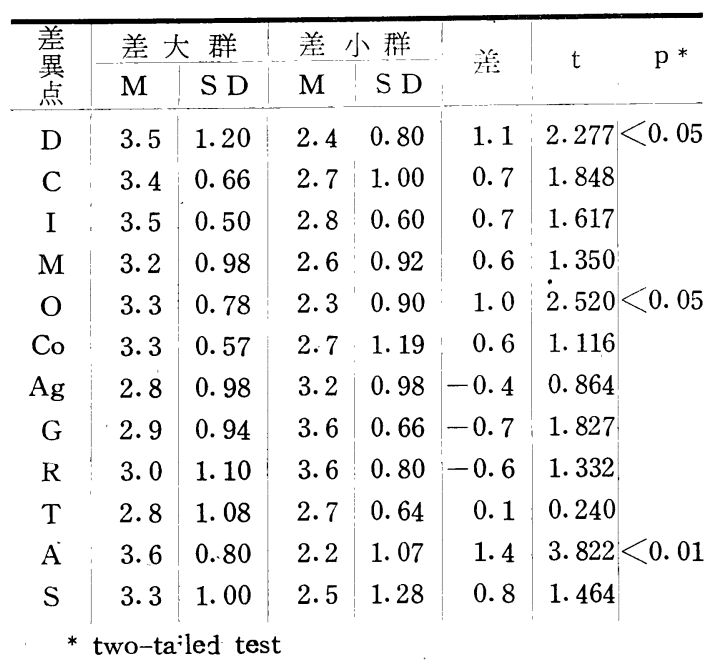

Table 5 D P の差大・差小群のYG得点に打ける比较

\begin{tabular}{|c|c|c|c|c|c|c|c|}
\hline \multirow{2}{*}{$\begin{array}{l}\text { 差 } \\
\text { 異 } \\
\text { 点 }\end{array}$} & \multicolumn{2}{|c|}{ 差 大群 } & \multicolumn{2}{|c|}{ 差小臂 } & \multirow{2}{*}{ 差 } & \multirow{2}{*}{$\mathrm{t}$} & \multirow{2}{*}{$\mathrm{p}$} \\
\hline & $\mathrm{M}$ & S D & $\mathrm{M}$ & $\mathrm{SD}$ & & & \\
\hline $\mathrm{D}$ & 3.6 & 0.66 & 2.4 & 0.66 & 1.2 & 3.852 & $<0.01$ \\
\hline $\mathrm{C}$ & 3.4 & 1.02 & 2.5 & 0.67 & 0.9 & 2.21 & $<0.05$ \\
\hline I & 3.3 & 0.78 & 2.9 & 0.70 & 0.4 & 0.114 & \\
\hline $\mathrm{N}$ & 3.6 & 0.36 & 2.7 & 0.90 & 0.9 & 2.403 & $<0.05$ \\
\hline 0 & 3.2 & 0.98 & 2.3 & 0.64 & 0.9 & 2.295 & $<0.05$ \\
\hline $\mathrm{Co}$ & 3.3 & 0.78 & 2.3 & 1.00 & 1. 0 & 2.370 & $<0.05$ \\
\hline$-A g$ & 3.1 & 0.70 & 2.4 & 0.66 & 0.7 & 2.184 & $<0.05$ \\
\hline G & 3.5 & 0.81 & 3.2 & 0.40 & 0.3 & 0.999 & \\
\hline $\mathrm{R}$ & 3.1 & 0.71 & 3.2 & 0.60 & -0.1 & 0.324 & \\
\hline $\mathrm{T}$ & 3.2 & 0.40 & 2.6 & 0.69 & 0.6 & 2.250 & $<0.05$ \\
\hline A & 2.9 & 1.04 & 3.1 & 0.83 & -0.2 & 0.450 & \\
\hline $\mathrm{S}$ & 3.0 & 0.89 & 3.1 & 1.04 & -0.1 & 0.219 & \\
\hline
\end{tabular}

Table 6 D P の差大・差小群の Y G 得点にお ける比較

\begin{tabular}{|c|c|c|c|c|c|c|c|}
\hline \multirow{2}{*}{$\begin{array}{l}\text { 翼 } \\
\text { 点 }\end{array}$} & \multicolumn{2}{|c|}{ 差 大群 } & \multicolumn{2}{|c|}{ 差 小群 } & \multirow{2}{*}{ 差 } & \multirow{2}{*}{$t$} & \multirow{2}{*}{$\mathrm{p}$} \\
\hline & M & S D & M & S D & & & \\
\hline$D$ & 3.2 & 0.60 & 2.5 & 0.81 & 0.7 & 2.10 & $<0.05$ \\
\hline $\mathrm{C}$ & 3.5 & 0.81 & 2.9 & 1.14 & 0.6 & 1.332 & \\
\hline I & 3.3 & 0.78 & 3.1 & 0.70 & 0.2 & 0.570 & \\
\hline $\mathrm{N}$ & 2.9 & 0.94 & 3.0 & 1.10 & -0.1 & 0.207 & \\
\hline $\mathrm{O}$ & 3.3 & 0.46 & 2.5 & 1.02 & 0.8 & 2. 136 & $<0.05$ \\
\hline $\mathrm{Cb}$ & 2.9 & 0.70 & 2.5 & 0.92 & 0.4 & 1. 032 & \\
\hline $\mathrm{Ag}$ & 3.0 & 0.77 & 2.8 & 0.69 & 0.2 & 0.516 & . \\
\hline G & 3.4 & 1.02 & 3.5 & 0.81 & -0.1 & 0.231 & \\
\hline $\mathrm{R}$ & 3.4 & 1.28 & 3.4 & 0.80 & 0 & 0 & \\
\hline $\mathrm{T}$ & 2.9 & 0.94 & 2.8 & 0.60 & 0.1 & 0.267 & \\
\hline A & 3.0 & 0.77 & 2.9 & 0.83 & 0.1 & 0.264 & \\
\hline $\mathrm{S}$ & 2.9 & 1.37 & 3.0 & 1.10 & -0.1 & 0.171 & \\
\hline
\end{tabular}

Table 7 D PFa の差大・差小群の $\mathrm{YG}$ 得点に おける比焏

\begin{tabular}{|c|c|c|c|c|c|c|c|}
\hline \multirow{2}{*}{$\begin{array}{l}\text { 差 } \\
\text { 異 } \\
\text { 点 }\end{array}$} & \multicolumn{2}{|c|}{ 差 大群 } & \multicolumn{2}{|c|}{ 差 小群 } & \multirow{2}{*}{ 差 } & \multirow{2}{*}{$\mathrm{t}$} & \multirow{2}{*}{$\mathrm{p}$} \\
\hline & M & S D & $\mathrm{M}$ & S D & & & \\
\hline $\mathrm{D}$ & 3.6 & 0.80 & 2.5 & 0.81 & 1. 0 & 2.904 & $<0.01$ \\
\hline $\mathrm{C}$ & 3.4 & 0.92 & 2.9 & 1. 04 & 0.5 & 1.08 & \\
\hline I & 3.4 & 0.66 & 3.1 & 0.70 & 0.3 & 0.936 & \\
\hline $\mathrm{N}$ & 2.9 & 0.94 & 2.7 & 1. 19 & 0.2 & 0.396 & \\
\hline $\mathrm{O}$ & 3.3 & 0.46 & 2.4 & 1. 11 & 0.9 & 2.241 & $<0.05$ \\
\hline Co & 3.2 & 0.87 & 2.7 & 1.00 & 0.5 & 0.788 & \\
\hline $\mathrm{Ag}$ & 2.7 & 0.90 & 2.7 & 0.90 & 0 & 0 & \\
\hline $\mathrm{G}$ & 2.2 & 1. 10 & 3.4 & 0.80 & -0.1 & 0.222 & \\
\hline $\mathrm{R}$ & 2.0 & 0.71 & 3.1 & 0.94 & -0.1 & 0.255 & \\
\hline $\mathrm{T}$ & 3. 0 & 0.89 & 2.7 & 0.64 & 0.3 & 0.81 & \\
\hline A & 3.5 & 0.92 & 2.8 & 0.87 & 0.7 & 1.659 & \\
\hline S & 3.2 & 1. 17 & 3.1 & 1. 10 & 0.1 & 0.186 & \\
\hline
\end{tabular}

$\mathrm{D}_{\mathrm{PI}}$ の大きいものは小さいものに比べて, D（抑うつ 性), $\mathrm{O}$ (主観性)， A (服従性) が有意に大きい。

同様に $\mathrm{D}_{\mathrm{PF}}$ では $\mathrm{D}$ (抑うつ症), $\mathrm{C}$ (気分変化大), $\mathrm{N}$ (神経質), $\mathrm{O}$ (主観性), $\mathrm{Co}$ (非協調性), $\mathrm{Ag}$ (攻撃性), $\mathrm{T}$ (思考的内向性) で有意な差がみられた。

D PM ではD(抑らつ性), O(主観性) が大きい傾向が みられる。

$\mathrm{D}_{\mathrm{PF}} \mathrm{a}$ では $\mathrm{D}_{\mathrm{PM}}$ と同じく，D，O スュアに有意な差 がみられ。

本研究の場合, 4 つの差異点の大きいものは抑らつ性, 主観性を示寸点は共通である。DPFは 7 つの領域で有意 差を示したのは注目に値する。 
Table 8 差異点とYG因子得点との相関係数

\begin{tabular}{|c|c|c|c|c|c|}
\hline YG因子 & $\begin{array}{c}\text { 情緒安定性 } \\
\mathrm{D}, \mathrm{C}, \mathrm{I}, \mathrm{N}\end{array}$ & $\begin{array}{c}\text { 社会適応 性 } \\
\mathrm{O}, \mathrm{Co}, \mathrm{Ag}\end{array}$ & 衝 $\mathrm{G}, \mathrm{\text { 動 }}$ 性 & 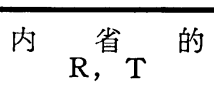 & 主 $\mathrm{A}, \mathrm{\text { 尊 }} \mathrm{S}$ 性 \\
\hline$D_{P}$ & $\begin{array}{l}\mathrm{n}=55 \\
\mathrm{r}=0.367^{* *}\end{array}$ & $\begin{aligned} \mathrm{n} & =55 \\
\mathrm{r} & =0.188\end{aligned}$ & $\begin{array}{l}\mathrm{n}=55 \\
\mathrm{r}=-0.256\end{array}$ & $\begin{array}{l}\mathrm{n}=55 \\
\mathrm{r}=-0.102\end{array}$ & $\begin{aligned} \mathrm{n} & =55 \\
\mathrm{r} & =0.322^{*}\end{aligned}$ \\
\hline$D_{P F}$ & $\begin{array}{l}\mathrm{n}=55 \\
\mathrm{r}=0.372^{* *}\end{array}$ & $\begin{array}{l}\mathrm{n}=55 \\
\mathrm{r}=0.340^{*}\end{array}$ & $\begin{array}{l}\mathrm{n}=55 \\
\mathrm{r}=-0.035\end{array}$ & $\begin{array}{l}\mathrm{n}=55 \\
\mathrm{r}=-0.095\end{array}$ & $\begin{array}{l}\mathrm{n}=55 \\
\mathrm{r}=0.020\end{array}$ \\
\hline $\mathrm{D}_{\mathrm{PM}}$ & $\begin{aligned} \mathrm{n} & =55 \\
\mathrm{r} & =0.299^{*}\end{aligned}$ & $\begin{array}{l}\mathrm{n}=55 \\
\mathrm{r}=0.299^{*}\end{array}$ & $\begin{array}{l}\mathrm{n}=55 \\
\mathrm{r}=-0.090\end{array}$ & $\begin{array}{l}\mathrm{n}=55 \\
\mathrm{r}=-0.089\end{array}$ & $\begin{array}{l}\mathrm{n}=55 \\
\mathrm{r}=0.109\end{array}$ \\
\hline $\mathrm{D}_{\mathrm{PF} a}$ & $\begin{aligned} \mathrm{n} & =50 \\
\mathrm{r} & =0.343^{*}\end{aligned}$ & $\begin{array}{l}\mathrm{n}=50 \\
\mathrm{r}=0.318^{*}\end{array}$ & $\begin{array}{l}\mathrm{n}=50 \\
\mathrm{r}=-0.209\end{array}$ & $\begin{array}{l}\mathrm{n}=50 \\
\mathrm{r}=-0.203\end{array}$ & $\begin{array}{l}\mathrm{n}=50 \\
\mathrm{r}=0.228\end{array}$ \\
\hline
\end{tabular}

さて, 差異点とY G性格検查での適応との関係をもつ とはつきりさせるために，おのおのの差異点と Y G 性格 検査の各因子得点との相関を見てみよう (Table 8)。

D P I は情緒安定性, 主導性と有意な相関をもつてい る。すなわち，DPI が大きい者ほど，情緒不安定で非 主導的であるということである。 DPF, DPM, DPFa はともに情緒安定性, 社会適応性と有意な相関がみられ る。具体的には，これらの差異点が大きい者ほど情緒不 安定で社会的不適応を示すことがわかる。こう見てくる と，4つの差異点は共通に情緒不安定性の指標であり， DPI はその他に非主導性, 他の 3 つは社会的不適応の 指標となつている。

\section{4. 考察}

4つの差異点は抑らつ性, 主観性の点で敏感であつた。 もつと大きい分類項目でいうと，すべて情緒性に関する 適応の指標としての意味をもつているとい方らうこの らちで D P I が自由連想検査でみた情緒性と密接な関係 をもつているといらことは, Robert（1952）によつてす でに指摘されているが，対人関係を前提とする他者自己 と垷実自己の差も情緒性に影響をもつているということ は興味深い。理想自己は自己の発展の目標, あるいは要 求水準といらかたちで自己を規定しているため，現実の 自己像とのずれがあるといら知覚は自己に対する不满と なり, 一方, 日常場面で, 有意味な関係をもつている他 者が自分のみているょうに見ていないといら知覚は将来 起こるかもしれない障害に対する不安感をひきおこしや すいからであろう。D P I 情緒性の他に非主導性の指 標ともなつている。DPF，DPM，DPFaはとを情緒 性の他に社会的不適応と密接な関係をむち，これは情緒 性の場合と異なり, 社会的不適応的諸行動が差異点の増 大をるたらしていると考えられる。このよらに D P I と 他の 3 つの差異点は異なつた適応領域を示すと解釈して
よかろう。したがつて, 長島（1962）も主張するように 適応の指標としては D P I みでは不十分で, 有意味な 他者がぞう自分をみているといらことと現実自己のずれ をも導入することによつて，適応の予測の精度は増大す るといえる。

本研究の 4 つの指標のうちで, DPF が Y G 性格検査 で最も多く7つの有意差を示している。これは被験者が 大学 2 年生であり, 比較的閉鎖的な大学での公私にわた る友だちとの交際がその生活および人格形成に重要な役 割りをはたしているので, 現実自己（ $S_{P}$ ) と友人自己 $\left(S_{F}\right)$ との不一致は, そのまま個人的・社会的適応に結 びつくためではないかと思われる。

\section{精神分裂病者と大学生とにおけ る差異点の比較}

\section{1. 目 的}

ここでは 4 つの差異点について, 精神分裂病者と大学 生の間の差を比較するが，一般に精神分裂病者の方が大 学生より差異点は大であると思われる。また, 雨群の弁 別においてどの指標が有効であるかという点と，さらに 自己記述尺度の下位尺度を構成する 6 つの因子のいずれ において両群を弁別しているかを分析することを目的と する。

\section{2. 方 法}

被験者：精神分裂病者として，山形市，上山市の精神 病院に入院加療中の者で検査可能の状態にあつた男性 22 名。このうち，資料に欠損部のあつた者10名を除いて12 名を分析の対象とした。大学生被験者は先に用いた山形 大学生55名のうち12名を無作為に抽出した。

測定用具：先に用いた自己記述尺度38項目。これは因 子分析の結果 6 つの因子に分かれている。第 I 因子（意 欲性, 強じん性因子）10項目，第II 因子（情動安定性因 
子） 10 項目，第而因子（社会性因子） 8 項目，第IV因子 （敏感性因子） 4 項目，第 V因子（緊張性因子） 4 項目, 第VI因子（理知性因子） 3 項目。このらち 1 項目はV, VI因子に同時に属している（長島貞夫ほか，1966）。

手続き：大学生については，先に述べたと拈りである が，精神分裂病者に対しては病院へ関係している臨床心 理学者がよく説明し, 動機づけながら, 自己記述尺度に 反応させた。施行順序は $\mathrm{S}_{\mathrm{P}}, \mathrm{S}_{\mathrm{I}}, \mathrm{S}_{\mathrm{F}}, \mathrm{S}_{\mathrm{M}}, \mathrm{S}_{\mathrm{F}}$ a の順 であつた。実施は1965年 9 月 6 日〜10日になされた。

結果の処理：先と同様にして, $D_{P I}, D_{P F}, D_{P M}$, $D_{P F}$ a 4 つの差異点を算出し，さらに 6 つの因子につ いても含まれる項目数を考慮して，差異点を算出した。 これらの差異点について精神分裂病者と大学生の間の差 の有意性をも検定によつてみた。

\section{3. 結 果}

精神分裂病者群と大学生群の差異点の平均を比較した 結果は, Table 9 〜 12 に示すと打りである。例外なく, 精神分裂病者群の方が大きい值を示している。個々の差 異点について見ていくと，DPIは全項目で有意な差が見 られる。因子毎に見ると $F_{1}$ (意欲性, 強じん性), $\mathrm{F}_{2}$ (情動安定性), $\mathrm{F}_{3}$ (社会性), $\mathrm{F}_{4}$ (敏感性) は $1 \%$ 水淮

Table 9 DPI に拈ける分裂病群・大学生群の比較

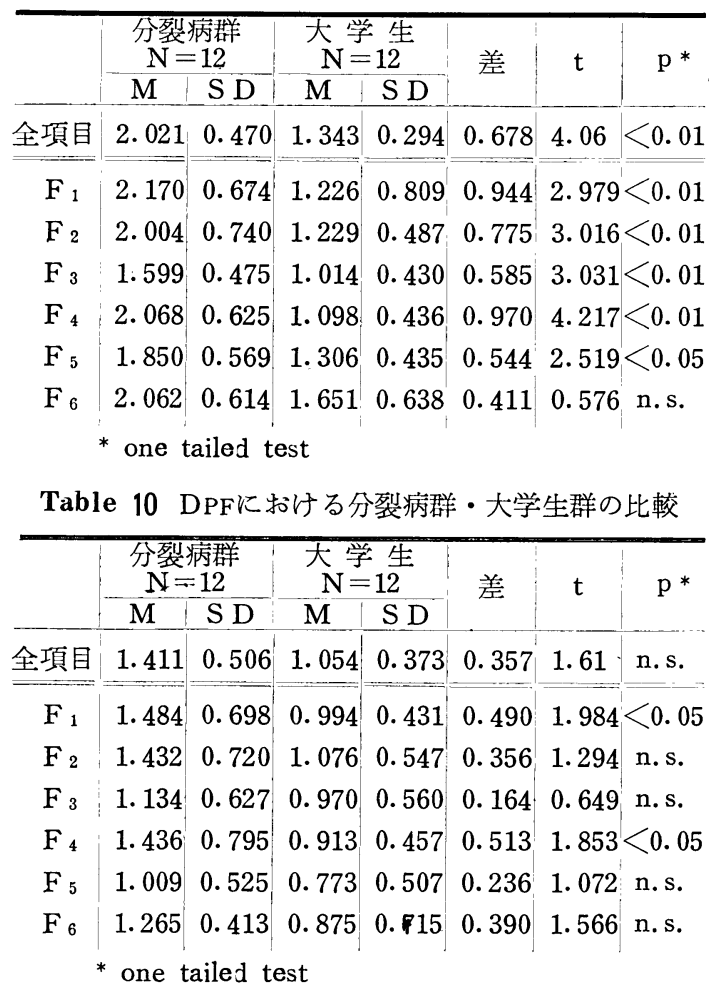

で有意であり， $F_{5}$ (緊張性) は $5 \%$ 水淮で有意である Table 9)。DPF は全体として差がないが， $\mathrm{F}_{1} ， \mathrm{~F}_{4}$ に おいて有意差がある（Table 10)。 $\mathrm{D}_{\mathrm{P} M}$ も全体として差 が見られず，因子別では， $\mathrm{F}_{1}$ に傾向が見られ， $\mathrm{F}_{6}$ で有 意差がある (Table 11)。DPFa は全体として有意差があ る。因子別では $\mathrm{F}_{1}, \mathrm{~F}_{2}, \mathrm{~F}_{5}, \mathrm{~F}_{4}$ の 4 つにおいて有意 差がある（Table 12）。

Table 11 DPMに拈ける分裂病群・大学生群の比較

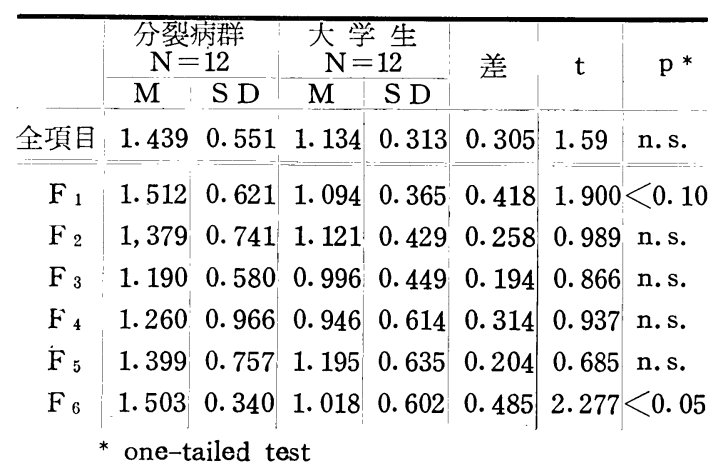

Table 12 DPFaに打列分裂病群・大学生群の比較

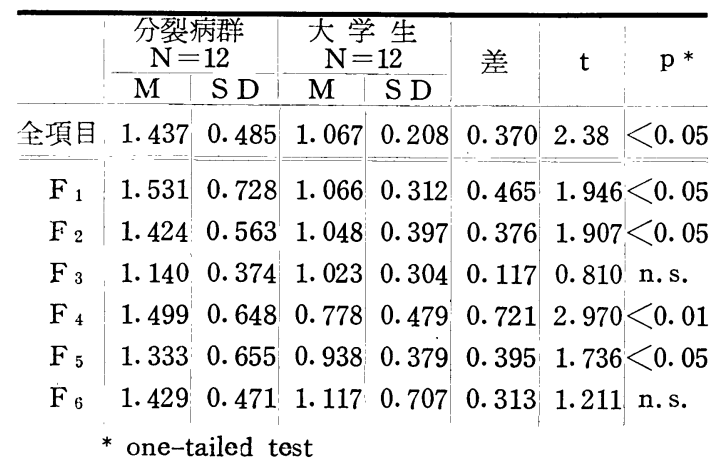

\section{4. 考察}

4 種の 差異点について精神分裂病者 と大学生の弁別 力を検討してみよう。D PIは6つの因子のうち5つにお いて大きな升別力を示している。 $F_{1}$ は意欲性, 積極性, 強じん性を示す因子で, $\mathrm{F}_{2}$ は幸福感, あたたかさ，情 動安定性など， $\mathrm{F}_{3}$ 社会性と命名されているが，向性，ま じめさ，地味などを示し， $\mathrm{F}_{4}$ は敏感性， $\mathrm{F}_{5}$ は繁張性を 示すのであるが上の結果は, Friedman (1955)やWochel and Hillson (1957)の結果と一致しない。かれらは，正 常者群と神経症者群と精神分裂病者群との $\mathrm{D}_{\mathrm{P}}$ （かれら は $\mathrm{D}_{\mathrm{SI}}$ とている) を比較して, 正常者群(大学生群)と 神経症者群とには有意な差があるが, 正常者群と精神分 裂病者群とには有意差が得られなかつたとしている。精 神分裂病者群では現実自己を高く評定し, 理想自己につ 
いては低く評定するという防衛型 (defense patterns)に よつてそのよらな結果がもたらされるものとしている。 本研究の結果は Table 9 に示したと扣り大学生と分裂病 者との間に有意差が見られるがどらしてであろらか。考 它られる原因としては本研究の分裂病者群は, 軽症者要 たは治療が進み回復過程にあり, 神経症者状態にあつ たのではないか，などがあるが，結論については今後の いつそら撖密な手続きによる研究にまつこととしたい。

$\mathrm{DPF}_{\mathrm{P}}$ も $\mathrm{F}_{1}, \mathrm{~F}_{2}, \mathrm{~F}_{4}, \mathrm{~F}_{5}$ の 4 つの因子において, 両 群を㚏別しているが， $\mathrm{F}_{3}$ では有意差が見られない。先 の研究ではあまり適応との関係は影著でなかつたことか ら考觉ると一見奇異である。この差は分裂病者群におい て，不適応の生起に父親が一因となつていることを意味， しているのかもしれない。これらの被験者が男性である ことはその点で興味があるが，これを証する資料が泛し いので断定することは控えたい。

$\mathrm{D}_{\mathrm{P} M}$ と $\mathrm{D}_{\mathrm{PF}}$ では両群に差が見られなかつた。因子別 に見ると， $\mathrm{D}_{\mathrm{P} M}$ は $\mathrm{F}_{6}$ (理知性) で有意差があるが，こ れは解釈しないで指摘するにとどめておく。

これらから, 本研究に用いられた被験者群の場合に は, DPI が最も有效で，ついで $D_{\text {PF }}$ a が有効な適応の 指標となることがいえよう。先の研究のように普通の大 学生のなかでの適応の指標であると思われた $D_{P F}$ は分 裂病者と大学生の比較の際には有効でない。

因子ごとでは $\mathrm{F}_{1}$ (意欲性, 強じん性), $\mathrm{F}_{4}$ (敏感性) は差異点の種類にかかわらず，両群の升別に有効である といつてもよかろう。

\section{総括的考察：結論と今後の問題}

理想自己と現実自己の不一致は適応の指標として有効 であるが，その他に有意味な他者に諗知されていると思 ら自己と現実自己の羑も適応と重要な関係を持つといら 観点から，4 種の差異点と適応との関係を検討した。ま ず，最初は，大学生被験者を用い，4つの差異点のうち で， $\mathrm{D}_{\mathrm{PF}}$ が最も有効で敏感な適応の指標となることが 認められたが，次の精神分裂病者と大学生とを比較した 場合には $D_{P}$ 品も并別力がよく， D PFa もかなりの 弁別力を示した。しかし $D_{P F}$ はほとんど両群の升別に 寄与していない。このことから， D P F は青年期にあり， しかも大学のような閉じられた社会に生活する人びとの 適応の予測にのみ有効であることを示すといえよう。 DPM，DPFaはより低年令の場合に有効であると思われ る。調べようとする人にとつでどの程度有意味であるか によつて，指標としての有効性は左右されるようであ る。
いずれにしても，DPIのみを適応の指標とすることは 不十分であり， $D_{P F} ， D_{P F} a$ とともに用いていかなけれ ば, 情緒適応, 社会適応, その他広い領域での適応を予 測することはできない。本研究では他者自我を導入して 適応との関係を検討したわけであるが，現象学的わく組 みをのりこえて，客観的，外的条件之現実認知のずれ も適応に少なから嫎響を扣よぼすと考えられる。たと 亲ば，個体の属する集団成員あるいは有意味な他者の見 た個人の姿，TAT などに投影された自己像とのずれな どである。これらも考慮に入れていくことが必要であろ ら。この線に沿つた研究もすでに行なわれているが， (Friedman, 1955) 適応の指標の追求は古いようで新し い問題であり，一貫した結果は得られたとはいえないの が現状である。測定用具の改良，方法論的検討がなされ たうえで, 経験的, 实証的研究が積み重ねられていくべ きである。

\section{要 約}

現実自己と理想自己の差 (DPI) だけでなく，現実自 己，他者自己（友人，母，父から見られていると思う自 己）との差 $\left(D_{P F}, D_{P M}, D_{P F} a\right)$ も考慮すべきである との観点から，2つの研究を行ない，適応の指標として の有效性, 各差異点の関連する適応領域について検討し た。なお自己概念の測定には長島貞夫らにより開発され た自己記述（Self-Differential）尺度を用いた。最初は 大学生を対象として，Y G性格検査得点に関して, 差異 点の大小群の 比較をした。4つとも情緒性の指標とな $\eta$, 加えて $D_{P F}, D_{P M}, D_{P F a}$ は社会的適応の指標と なつた。なかでも $D_{P F}$ は最も多くの適応領域と有意味 な関係があつた。次には, 精神分裂病者群と大学生群の 比較を行ない， D P F , D P F aが両群を敏感に我別するこ とを見出した。とくにDPIは因子の 5 つにおいて升別し た。しかし，これは従来の結果と矛盾しているが，その 正確な説明は保留された。この比較では $D_{P F}, D_{P M}$ は あまり有効ではなかつた。第 1 因子（意欲性，強じん 性), 第 IV 因子（敏感性）は両群の弁別により有効であ る。以上の結果から，正常者内の比較の場合と正常者と 精神分裂病者間の比較の場合では適応の指標としての有 効性が異なるが，いずれにしても，Dpr のみでなく他者 自己とのずれを併用することは，広い適応領域にわたる 有効な予測を可能にすることが結論された。

今後の問題についても若干触れた。 
付表 1

氏名 性別 男 女 生年月日 昭和 年 月 日 学校

検査年月日 昭和 年 月 $日$

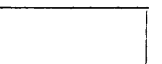
内のことで，次の38項目について例のごとくに自分でもっとも当てはまると思うところに○印をつけて ください。

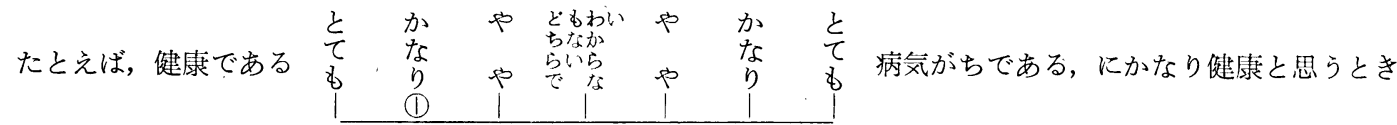
は例のごとくに○印をつけるのです。

なおこれはあなた個人を調べるためでなく，一般的な心理学の研究のためのものですから，あなたの思らあり のまま答えてください。

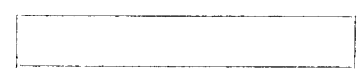

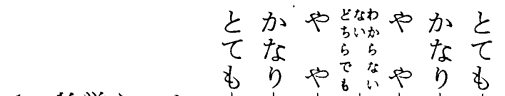
1. 物覚えのよい
忘れっぽい
2.かたい
やわらかい
3. 個性のない
個性的な
4. 不活発な
活発な
5. 敏感な

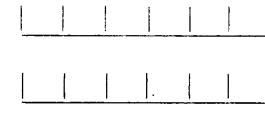
鈍感な
6. 厳しい
優しい
7. 明るい

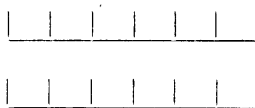
暗 い
8. 不安定な
安起な
9.草屈な

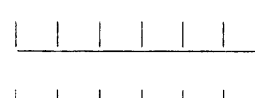
おおらかな
10. 暖 い
彾い
11. 病㐷な

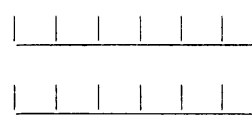
元気な
12. 気持覀い
気持よい
13. 地味な

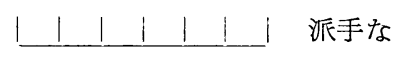
14.おしゃべりな

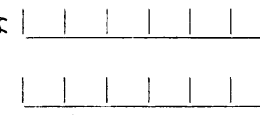
無口な
15. 不真面目な
真面目な
16. 清潔な
不絜な
17.こまかい

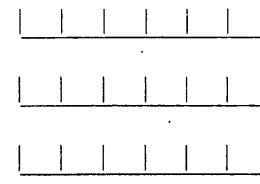
大まかな
18. 強気な
䏛気な
19. 哚い
浅

20.せっかちな

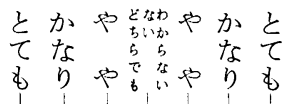

21. 強

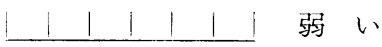

22. 臆病な

23. 冷静な

24. 感情的な

25.にぎやか

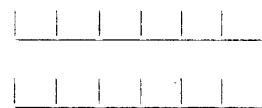

静かな

26. でしゃばりな

ひかえめな

27、幸福な

不幸な

28. 不誠実な

誠実な

29. 積極的な

消極的な

30. 内面的な

31. 軽卒な

外面的な

32、安らかな

33. 不注意な

34. 丸い

35. 意欲的な

36. 楽しい

37. 頼りない

38.きちんとした
慎重な

不安な

注意深い

角のある

無気力な

苦しい

頼もしい

だらしない 


\section{文献}

Bills, E. R, \& Mc Lean O. 1951 An index of adjustment and values. J. Consult. Psychol., 15, 257-261.

Friedman Ira, 1955 Phenomenological, ideal and projected conception of self. J. abnorm. soc. Psychol., 51, 611-615

長島貞夫 1962 操作的方法による自我の心理学的研究 野間教育研究所紀要 第21集

長島貞夫他 1966 自我と適応の関係についての研究

（I ）-Self-differential 作製の試み一 東京教育大 学教育学部紀要 第 12 巻
Robert G, E, 1952 A study of validity of the index of adjustment and values. J. consult. Psychol., 16, 302-304.

Rogers, C, R, \& Dymond, K, F. 1954 Psychotherapy and personality change. University of Chicago Press.

Snygg, D. \&Combs, A. W. 1949 An new frame of reference for psychology. New York, Harper.

Wochel, P. \& Hillson, J. S. 1957 Self-concept and defensive behavior in the maladjusted. $J$. consult. Psychol., 11, 81-88

（1966年 3 月 10 日原稿受付） 


\title{
STUDIES ON THE SELF CONCEPTS AS THE INDICES OF THE ADJUSTMENT
}

\author{
by \\ Nobuji Shiino \\ Yamagata University
}

Two experiments were designed to verify the gross assumption that as an index of adjustment, it is necessary but insufficient to use the only discrepancy between present self and ideal self, and so we should simultaneously use the discrepancies between present self and subject's perception of self as perceived by significant others (his friends, mother and father).

The first experiment aimed mainly to explore that each $D$ score would be the sensitive index for any aspects of the malajustment. 55 college student$s$ were given Self-Differential scales for measurement of five kinds of self concepts i. e. present self concepts, ideal-self concept, friend's self concept$s$, mother's self concept and father's self concept, and then YATABE-GUILFORD PERSONALITY INVENTORY with twelve subtests for measurement of adjustment. Four discrepancy scores between present self and four other self concepts (ideal self, friend's self, mother's self and father's self) were computed within each subjects. They are referred to as $D_{P I}, D_{P F}, D_{P M}$ and $D_{P F}$ a respectively. The latter three were the discrepancies between present self and the subject's notion of himself in his relation to his significant others. Each D score was related to Y. G. scores.

The following results were found.

a) All four D scores were proved to be the indices of emotional adjustment.

b) $D_{P F}, D_{P M}$ and $D_{P F a}$ except $D_{P I}$ were proved to be the indices of the social adjustment.

c) When the high $D_{P F}$ group was compared with low $D_{P F}$ group, statistically significant differences were found in seven subtests' score$s$ of $Y$. G. inventory. This means that $D_{P F}$ is the most effective index of adjustment.

The second experiment was designed to compare schizophrenic patients with normal students for each D score.

The findings were as follows:

a) $D_{P I}$ discriminated both groups sensitively in five of six factors of Self-Differential.

b) $\mathrm{D}_{\mathrm{PF} \text { a }}$ discriminated two groups in four factors.

c) $\mathrm{D}_{\mathrm{P} F}$ and $\mathrm{D}_{\mathrm{P}}$ were not so effective in discriminating two groups.

d) With respect to Self Differential factors, three D scores (except DPM) discriminated two group$s$ in factor I (volition and toughness) and factor IV (sensibility).

e) Only $D_{P I}$ discriminated in factor III (sociability including introversion-extroversion) and in factor VI (intelligence).

The following, therefore, can be concluded:

a) Within a normal student group, all four D scores can be seen to be the indices of emotional adjustment. Three D scores, not including the $D_{P}$, indices of social adjustment. Especially $D_{P F}$ is the most effective.

b) $D_{P I}$ and $D_{P F a}$ seem to be effective in comparing the normal with schizophrenic patients. Furthermore, the schizophrenic person tends to represent greater discrepancies on the aspects of his volition-toughness, sensibility in his phenomenal world than the normal.

c) Finally it may be said that the predictability for the personal and social adjustment will be increased when we use not only $D_{P I}$ but $D$ scores reflecting the self-other context. 